\title{
The Impact of Strategic Management Accounting Techniques in Taking Investment Decisions in the Jordanian Industrial Companies
}

\author{
Sufian Salameh Jbarah ${ }^{1}$ \\ ${ }^{1}$ Assistant Accounting Professor, Irbid National University, Irbid, Jordan \\ Correspondence: Sufian Salameh Jbarah, Assistant Accounting Professor, Irbid National University, Irbid, \\ Jordan.
}

Received: October 17, 2017

Accepted: December 4, 2017 Online Published: December 19, 2017

doi:10.5539/ibr.v11n1p145

URL: https://doi.org/10.5539/ibr.v11n1p145

\begin{abstract}
This research aimed to identify the impact of strategic management accounting techniques in taking investment decisions in the Jordanian industrial companies. The population of the study included all the Jordanian industrial companies while the sample consisted of (93) respondents from the investors and financial mediators in Amman stock market. The research revealed the presence of an effect of the strategic management accounting techniques with its variables (target costing, balanced scorecard, just in time production system) in taking investment decisions in the Jordanian industrial companies. In the light of the results, the researcher presented a number of recommendations, most prominently: using the strategic management accounting techniques by the Jordanian industrial companies and caring for its different fields to be able to interact and respond to the environmental, social and economic variables.
\end{abstract}

Keywords: Jordanian industrial companies, strategic management accounting techniques, taking investment decisions

\section{Introduction}

In recent times, the world witnessed great growth in different organizations. The traditional costing systems became invalid to cope with that revolution which led to the appearance of modern and developed systems that agree with this technological development. With the increasing development in the costing systems, many management accounting systems immerged representing a tangible development and a method for the accurate identification of the products cost whether commodity or services (Al-Nashshar, 2014, P35).

Therefore, organizations are seeking to change their policy to move from their present situation to the one they desire to occupy in future. This movement mostly requires taking certain administrative procedures which are normally taken after a phase of measurement and assessment. The ability to measure and assess something is one indicator to the capacity of its management. Moreover, the development in business fields led to the variety of the activities practiced by the organization and multiplicity of the products it produces. This trend complicated the administrative operations such as planning, organization, guidance and control as well as decision making.

For that reason, it was important to use modern administrative methods and techniques which enable organizations to verify the efficiency of using the available resources in realizing the desired objectives. This can be done through the information methods that help to search for the best of those uses with the least production cost as sound information leads to sound decisions (Fakhre\& Al-Dulaimi, 2012, P5).

Since organizations focus on the quality of their products and the classification of their operations into multiple activities to attain more accurate information for the cost of their products, and as a result of the different changes in information technology and the tastes of consumers the role of administrative accountant changed from the traditional role of providing information to a more effective role by putting it within the integrated administrative team which seeks to planning and taking proper decisions to realize the best profits for the organization (Zaher, 2016, P15).

\section{The Problem and Elements of the Research}

The basic problem of the research is attempt to identify the management accounting techniques as untraditional accounting methods and whether using those techniques helps in improving the process of taking investment decisions in the Jordanian industrial companies, in addition to evaluating those decisions in a manner that 
realizes balance in performance, and whether they have contributed in maximizing the returns of revenues as a financial measure, or contributed in raising the level of satisfaction among the shareholders and investors in those companies and increasing confidence indicators in the transaction of clients as non-financial indicators. Thus, while the management accounting methods seek planning and taking proper decisions to realize best profits for the company, this research presents the following question: Is there an impact of the strategic management accounting techniques in taking investment decisions in the Jordanian industrial companies?

\section{Objectives of the Research}

The main goal of this research is identifying the impact of strategic management accounting techniques with its variables (target costing, balanced scorecard, just in time production system) in taking investment decisions in the Jordanian industrial companies.

\section{Importance of the Research}

The importance of the research appears under the fast and constant development in this field making it a fertile domain which requires directing the attention toward the development of management accounting techniques in the Jordanian industrial companies to be utilized by investors in taking investment decisions in those companies.

\section{Hypotheses of the Research}

The main hypothesis of the research was coined as follows: there is no statistically significant effect of the strategic management accounting techniques with its variables (target costing, balanced scorecard, just in time production system) in taking investment decisions in the Jordanian industrial companies.

\section{Model of the Research}

Independent variables

\begin{tabular}{|l|l|}
\hline $\begin{array}{l}\text { Strategic management accounting } \\
\text { techniques: }\end{array}$ \\
- Target costing \\
- Balanced scorecard \\
- Just in time production system
\end{tabular}$\longrightarrow$ Taking investment decisions

Figure 1. Model of the Research

\section{Methodology of the Research}

This research is one of the field researches in which the researcher followed the analytical descriptive method to identify the impact of strategic management accounting techniques in taking investment decisions in the Jordanian industrial companies.

\subsection{Population and Sample of the Research}

The population includes all the industrial companies listed in Amman stock market counting (56) companies according to (the annual report of Amman stock market for the year 2016), and the inspection unit consists of the investors and financial mediators in Amman stock market whereupon (125) questionnaires were distributed following the available method. (93) questionnaires were retrieved and adopted for the statistical analysis purposes at the rate of $(74.4 \%)$.

\subsection{Collecting Data, Validity and Reliability}

\subsubsection{The Tool of Collecting Data and Validity and Reliability}

The researcher designed a questionnaire which covered all the axes of the research according to Likert Scale quintet with five grades (strongly agree 5 marks, agree 4 marks, agree somewhat 3 marks, not agree 2 marks, strongly not agree 2 marks). Cronbach's Alpha coefficient was used where the reliability degree reached at $(90.3 \%)$ which is accepted and reliable to generalize the results.

\subsubsection{Statistical Treatment}

The researcher used the statistical method (SPSS) in analyzing data where he used the arithmetic means and standard deviation with the simple multiple linear regression analysis to the test hypotheses. 


\subsubsection{Data Collection Methods}

The researcher depended on two types of information sources:

First: The primary sources: The data attained through the questionnaire of the field research.

Second: The secondary sources:The data attained from desk sources like books, scientific material, reports and researches related to management accounting techniques and decision making.

\section{Previous Studies}

Abu Zaid (2010) conducted a study which aimed at assessing the traditional costing systems and methods of their development and studying the role of target costing system to achieve a competitive advantage in oil and gas companies to enable them survive in the international markets.

The study of Jawad and Al-Rifa'i (2010) suggested that the sample company not to follow the scientific steps for taking the decision related to accepting a special order together with not making the deferential analysis of costs for its significant role in helping the manager in taking such decisions.

The results of the study of (Kee, 2010) showed that the traditional target costing model can lead to products which have negative present net value while it rejects the products with positive present net value. In addition, the mathematical analysis of the traditional target costing model indicates that it is a typical feature of the model.

The study of (Joudeh et al., 2011) indicated that most companies have a clear definition for management accounting and that the majority of these companies have independent divisions or persons in charge of applying the management accounting methods and that the use of management accounting methods in companies is weak generally especially the modern management accounting methods.

The study of (Adler et al., 2012) pointed out that the most companies use many modern methods without leaving the traditional management accounting methods. The research also indicated that the obstacles of adopting the modern methods are attributed to limitations related to the human resources of those companies.

The study of (Wegman, 2013) showed that the logic of (ABC) system remains the best to improve the management accounting systems for the purpose of leading the strategic decisions.

The study of (Jaradt\& Al-Shebli, 2014) pointed out that the information provided by management accounting contributes in the mergence of commercial banks through all stages.

The study of (Ghneimi, 2014) showed that applying the target costing method helps to support the competitive ability of the commercial bank's services and enhance achieving the strategic goals of the bank which are survival, growth and continuity in the prevailing competitive market of present time.

The results of the study of (Al-Tarawneh, 2015) showed that the costing method based on activity concentrates on activities as the main target of the cost and that the cost causes in the costing system give more accurate results than the traditional foundations.

Finally, the study of (Al-Nsour, 2016) indicated that the industrial companies apply the traditional management accounting methods more that the modern ones which means that there is still insufficient knowledge about the management accounting methods.

What distinguishes the present research: What gives distinction to this research is that it is not restricted on studying a specific technique concerning applying or not applying it. This research moved beyond this target to identify the impact of the strategic management accounting techniques in taking investment decisions in the Jordanian industrial companies.

\section{The Theoretical Framework}

\subsection{Management Accounting}

Management accounting went through many de velopment phases due to different economic, political, legal and social factors. It roots go back to the $19^{\text {th }}$ century when the management needed information about the costs in the industries of spinning and weaving, and iron and steel industry and other industries based on large size of production. The focus was mainly on cost and wages then extended to include the additional costs of products to participate in determining the cost of stocks in a better manner. (Joudeh et al., 2011, P.18).

Management accounting has an impressive role in the different aspects of economic life. It has to go with the requirements of society and the needs of managers which change rapidly. The $21^{\text {st }}$ century is witnessing a new era and a huge information jump, and since accounting is the offspring of economic needs, it had to consider these great technical developments and the revolution which created huge numbers of units with various 
activities from which are the giant multinational companies which produce different hi-tec goods and services. The age of information and communication technology produced new techniques with which the accountants are dealing especially the management accountants who have to be interested in developing information of quality and appropriation for decision making and to be distributed in the right time beside the importance of following up with management accounting as the main source to maintain the competitive ability to develop and adapt with those changes. The management accountant has no choice but to obtain a set of knowledge and skills and to know about aspects of creativity and thinking to find solutions to the problems that face organizations during decision making. The management accountants who cannot adapt with those changes will find it hard to compete in this expanding career. They will not be able to provide high quality professional services which will expose them to threats that may result in the impossibility to keep their jobs (Ali, 2016, P. 12-13).

For the purpose of this study, the researcher used three methods of management accounting which are: target costing, balanced scorecard, just in time production system and following is a brief account of those methods:

\subsubsection{First: Target Costing}

Target costing is the process of controlling and specifying the costs of the suggested product, and the quantity of production which generates the required profit at its expected selling price in the future. It is one of the cost management tools that reduce the total production cost during the life cycle of the product with the help of those in charge of production and designing engineering (Sakurai, 2008, P.39).

(Kato, 2003, P: 33) believes that the target costing system is one of the strategic tools that reduce the production cost of a product during its life cycle and it represents the "the set of activities that aim at reducing the costs of the high quality product life cycle and which meets the needs of the clients through examining all the ideas through which those costs can be reduce in the planning and developing stages".

Target costing is also defined as "The management costing planned and used in the preliminary stages of the product's design which affects the process of production according to the requirements of the market and it includes a group of activities that can be shaped and determined to reach at the required costing level, and it is usually divided into stages to facilitate achieving the financial targets planned by the management" (Yoshikawa, 2013, P: 33).

The researcher sees that the target costing is the controlling process which utilizes data and information in a logical series of steps to determine and realize the target costing of the product. It is one of the effective and inclusive costing systems which care for the coordination and organization of all stages of the project such as planning, designing, production and control.

\subsubsection{Second: Balanced Scorecard}

It is one of the modern administrative means presented by Kaplan \& Norton as a new concept of strategic management. This contemporary model presents a complete solution to the weakness and vagueness of the old attitude of the administrative system which concentrates on the financial performance through adding other dimensions that transform the strategic plan into tangible acts and results connecting the goals, means and measurements with the required level of performance and the programs with the strategic plan (Theresa et al., P: 20).

This card is an assessment and strategic tool at the same time because it adopts four axes to assess the performance of the organization namely: the financial axis, the internal operation axis, instead of concentrating on the financial perspective only which is insufficient to form a comprehensive image of the organization (Horngren, 2005, P: 448).

(Kaplan \$ Norton, 2005, P: 52) defined the balanced scorecard as "a tool which translates the mission and strategy of the company into goals and measurements and presents a solid set of ideas and principles in addition to a comprehensive course of the companies to follow the translation of the mission through an interconnected set of performance measurements. These measurements contribute in the accomplishment of the work, placing a strategy of the work, the connection of the strategy with the work and the coordination between the individual and organizational performance.

The researcher believes that the balances scorecard clarifies the strategic vision, improves performance, puts a series of goals, provides feedback for the strategy and connects rewards to performance standards. It also keeps the financial standards as a significant brief for the worker and management performance and sheds light on a set of measurements which are more general, interactive and interconnected between the consumer and the internal operations and workers and the performance of the system to realize a long-term financial success. 


\subsubsection{Third: Just in Time Production System}

Just in time production system is a method which depends on technology to limit the waste in time of purchase and production and to do without all types of stock in a way that reduces the costs of the production process, increases production and meets the client's needs in time with the specified quantities (Al-Bishtawi\& Al-Matarneh, 2007, P: 299).

(Schroeder, 2008, P: 189) argues that the concept of (JIT) goes beyond the control on stock to include the whole production system as it removes all sources of wastage and any activity that does not add value to production through producing the right product in the right place and right time that is production according to demand contrary to the traditional inlet which produces according to the specific case (Just-In-case), and the provision to the productive possibility which should be exploited as long as available and not according to the demand on just in time production.

(Adeyemi, 2010, P: 145) defined (JIT) as a system that works as a comprehensive strategy which combines the basic tactical elements that include: (JIT) purchase and (JIT) production to remove wastage and for the optimal use of resources in all the preparation chain.

The researcher believes that the philosophy of just in time production system is based on presenting new production concepts and methods which efficiently help in achieving a competitive position among the competitive companies. The power of this system appears in that its concepts change the prevailing concepts and principles as it exposed many negative aspects of the traditional administrative systems.

\subsection{Taking Investment Decisions}

The success of the investment process depends on the soundness and appropriation of the investment decision. This type of decisions has several properties that make it more important due to their fixed liabilities that cannot be adjusted or cancelled. Therefore, the success of the investment project depends on the investment decisions taken at the beginning of the project (Abu Jalil\&Akel, 2016, P: 114).

(Kuaider, 2012, P: 21) defined the investment decision as "The decision that dictates the allocation of a sum of funds at the present time and on the long run to achieve profits in the future and which is liable to different levels of risks".

Due to the great importance of the investment decision and the comprehension related to this concept, Abu Khashabeh (2011, P: 3 ) stated that the investment decision includes the following:

1 - Decisions to invest funds in investment projects which produce new production capacity.

2- An investment decision to expand current projects to increase the present production capacity of the project.

3- An investment decision to maintain or to increase the present production capacity to renew the present assets.

Taking investment decisions is connected to the decisions related to the long-term capitalistic investment which generates new production capacity and extends to long periods in the future. Most investments projects extend to long periods, and since the future is uncertain, the success or failure of such decisions depend on the accuracy of prediction about the future especially concerning the element of sales which is the corner stone in the investment decisions (Salem, 2015, P: 246).

(Zirar, 2013, P: 8-9) added that investment decision is non-repeated as the applied domains of the feasibility studies cannot be done except in distanced tine periods and it is a strategic decision which needs the ability to predict the future and holds fixed costs that cannot be adjusted or cancelled and it allows extends to future activities and mostly connected with a certain level of risks. The researcher argues that the investment decision is similar to any other decision in being the choice of the suitable alternative and it depends on the main goal of the investor which is maximizing the achieved return of the investment with an acceptable level of risk. Therefore, the investment decision can be defined as allocating a specific sum of funds in along period of time to achieve future profits and it is liable to the risks of uncertainty.

\section{Analyzing Data and Testing Hypotheses}

\subsection{Descriptive Statistics}

\subsubsection{First}

Results of the descriptive statistics of the data related to the variable (target costing) 
Table 1 . The arithmetic means and standard deviation (target costing)

\begin{tabular}{|c|c|c|c|c|c|}
\hline serial & items & $\begin{array}{l}\text { arithmetic } \\
\text { means }\end{array}$ & $\begin{array}{l}\text { standard } \\
\text { deviation }\end{array}$ & $\begin{array}{l}\text { level of } \\
\text { importance }\end{array}$ & sequence \\
\hline 1 & $\begin{array}{l}\text { Allocating specific expenses annually for research and } \\
\text { development. }\end{array}$ & 3.649 & .707 & medium & 3 \\
\hline 2 & $\begin{array}{l}\text { There are other geometric designs for products to } \\
\text { ensure the required technical specifications. }\end{array}$ & 3.627 & .719 & medium & 5 \\
\hline 3 & $\begin{array}{l}\text { The actual products are tested after production to } \\
\text { provide high quality and suitable prices for clients. }\end{array}$ & 3.461 & .761 & medium & 7 \\
\hline 4 & $\begin{array}{l}\text { Operation engineering can be designed in a way that } \\
\text { leads to reduce costs and to provide new models in the } \\
\text { future. }\end{array}$ & 3.690 & .729 & high & 2 \\
\hline 5 & $\begin{array}{l}\text { Production process can be managed in a way that } \\
\text { reduces the costs of products. }\end{array}$ & 3.099 & .818 & medium & 10 \\
\hline 6 & $\begin{array}{l}\text { The production operations design affects the costs of } \\
\text { products to provide products with better prices. }\end{array}$ & 3.511 & .817 & medium & 9 \\
\hline 7 & $\begin{array}{l}\text { The costs of products area affected by the storing costs } \\
\text { of raw materials and the requirements and prices of the } \\
\text { production process. }\end{array}$ & 3.812 & .742 & high & 1 \\
\hline 8 & $\begin{array}{l}\text { The demand can be predicted and studied to market the } \\
\text { products and determine the appropriate prices. }\end{array}$ & 3.498 & .811 & medium & 6 \\
\hline 9 & $\begin{array}{l}\text { Depending on several procedures to determine the } \\
\text { market's needs and to care for the opinions and } \\
\text { suggestions of clients. }\end{array}$ & 3.481 & .670 & medium & 7 \\
\hline 10 & $\begin{array}{l}\text { A handling system for raw materials and the } \\
\text { requirements of the production process can be provided } \\
\text { according to the needs and within certain validities. }\end{array}$ & 3.665 & .775 & medium & 4 \\
\hline
\end{tabular}

This variable was treated through ten items which realized an arithmetic mean of (3.549) with a standard deviation (.599) and since the arithmetic mean is less than (3.68), we can say that the effect of target costing in taking investment decisions in the Jordanian industrial companies is at a medium level, we notice that the item which states "The costs of products area affected by the storing costs of raw materials and the requirements and prices of the production process" took the first rank with an arithmetic mean of (3.812) and a standard deviation of (.742) with high level of effect, while the item which states "A handling system for raw materials and the requirements of the production process can be provided according to the needs and within certain validities" was the least among the means of responses with an arithmetic mean of (3.099) and a standard deviation of (.818) with a medium level of effect.

The researcher believes that the impact of the target costing is reflected upon the need to improve the product and its features, modifying the operation, methods, simplifying the design to improve the quality and meeting the desires of clients. This shows the importance of dealing with the target costing in taking investment decisions in the Jordanian industrial companies. 


\subsubsection{Second}

Results of the description statistics of the data related to $\mathrm{T}$ the balanced Scorecard)

Table 2.The arithmetic means and standard deviation (balanced scorecard)

\begin{tabular}{|c|c|c|c|c|c|}
\hline serial & items & $\begin{array}{l}\text { arithmetic } \\
\text { means }\end{array}$ & $\begin{array}{l}\text { standard } \\
\text { deviation }\end{array}$ & $\begin{array}{l}\text { level of } \\
\text { importance }\end{array}$ & sequence \\
\hline 11 & $\begin{array}{l}\text { The company clarifies its strategy to the shareholders } \\
\text { and determines its strategic goals clearly. }\end{array}$ & 3.271 & .697 & medium & 8 \\
\hline 12 & $\begin{array}{l}\text { The company cares for performance measurements to } \\
\text { accomplish its works and puts work strategies } \\
\text { connected to works. }\end{array}$ & 3.459 & .651 & medium & 4 \\
\hline 13 & $\begin{array}{l}\text { The company coordinates between the individual and } \\
\text { organizational performance. }\end{array}$ & 3.589 & .702 & medium & 2 \\
\hline 14 & $\begin{array}{l}\text { The company has a clear plan to achieve the strategic or } \\
\text { tactical goals and to facilitate the process of preparing } \\
\text { the annual budget. }\end{array}$ & 3.410 & .840 & medium & 6 \\
\hline 15 & $\begin{array}{l}\text { The company seeks to increase the administrative } \\
\text { harmony among the workers and to build organizational } \\
\text { knowledge to help them improve their abilities. }\end{array}$ & 3.457 & .604 & medium & 5 \\
\hline 16 & $\begin{array}{l}\text { The company is interested in performance measurement } \\
\text { operations and the connection of the short-term } \\
\text { operational control with a long-term vision and strategy. }\end{array}$ & 3.252 & .730 & medium & 9 \\
\hline 17 & $\begin{array}{l}\text { The company translates its strategy into specific goals, } \\
\text { target measurements and standards and initiatives for } \\
\text { continuous improvement. }\end{array}$ & 3.335 & .612 & medium & 7 \\
\hline 18 & $\begin{array}{l}\text { The company communicates the strategy to all the } \\
\text { employees and spreads the organizational change and } \\
\text { learning. }\end{array}$ & 3.559 & .899 & medium & 3 \\
\hline 19 & $\begin{array}{l}\text { The company attempts to harmonize the individual } \\
\text { goals and the division's goals with its strategy. }\end{array}$ & 3.774 & .716 & high & 1 \\
\hline \multicolumn{2}{|c|}{ balanced scorecard } & 3.456 & .584 & medium & \\
\hline
\end{tabular}

This variable was treated through nine items with an arithmetic mean of (3.456) and a standard deviation of (.584), and since the arithmetic mean is less than (3.68) we can say that the effect of the balanced scorecard in taking investment decisions in the Jordanian industrial companies was medium. We notice that the item which states "The company attempts to harmonize the individual goals and the division's goals with its strategy" took the first rank with an arithmetic mean of (3.774) and a standard deviation of (.716) with high level of effect, while the item which states "The company is interested in performance measurement operations and the connection of the short-term operational control with a long-term vision and strategy" was the least among the means of responses with an arithmetic mean of (3.252) and a standard deviation of (.730) with a medium level of effect.

The researcher believes that the balances scorecard is a developed method in the work that requires many assessment tools. It is of the most important management accounting techniques used in the assessment process which depends on the financial and non-financial performance measurements and it consequently contributes in measuring the development of the products produced by the Jordanian industrial companies in a manner that leads to rationalize their cost which maximizes the revenue of those companies. 


\subsubsection{Third}

Results of the descriptive statistics of the data related to the variable (just in time production system)

Table 3. The arithmetic means and standard deviation (just in time production system)

\begin{tabular}{|c|c|c|c|c|c|}
\hline serial & items & $\begin{array}{l}\text { arithmetic } \\
\text { means }\end{array}$ & $\begin{array}{l}\text { standard } \\
\text { deviation }\end{array}$ & $\begin{array}{l}\text { level of } \\
\text { importance }\end{array}$ & sequence \\
\hline 20 & $\begin{array}{l}\text { Just in time production system helps to control the final } \\
\text { delivery time to clients which enhances the competitive } \\
\text { ability. }\end{array}$ & 3.461 & .877 & medium & 5 \\
\hline 21 & $\begin{array}{l}\text { (JIT) production system reduces the size of stock and } \\
\text { the costs. }\end{array}$ & 3.481 & .773 & medium & 4 \\
\hline 22 & $\begin{array}{l}\text { (JIT) makes the delivery of stock depend on a limited } \\
\text { number of suppliers. }\end{array}$ & 3.689 & .645 & high & 1 \\
\hline 23 & $\begin{array}{l}\text { The use of production control cards contributes in } \\
\text { controlling production and the required specifications. }\end{array}$ & 3.373 & .678 & medium & 9 \\
\hline 24 & $\begin{array}{l}\text { (JIT) system leads to providing workers with multiple } \\
\text { skills. }\end{array}$ & 3.466 & .707 & medium & 5 \\
\hline 25 & $\begin{array}{l}\text { (JIT) system helps to purchase stock with quantities } \\
\text { appropriate to the size of production. }\end{array}$ & 3.510 & .708 & medium & 3 \\
\hline 26 & $\begin{array}{l}\text { (JIT) system is connected to improving the quality of } \\
\text { the product and in reducing its costs through the testing } \\
\text { and controlling procedures. }\end{array}$ & 3.379 & .684 & medium & 8 \\
\hline 27 & $\begin{array}{l}\text { (JIT) system enables to depend on a law level of stock } \\
\text { to lessen the loss. }\end{array}$ & 3.561 & .588 & medium & 2 \\
\hline 28 & $\begin{array}{l}\text { (JIT) system enables the company to produce according } \\
\text { to specific orders. }\end{array}$ & 3.411 & .644 & medium & 7 \\
\hline \multicolumn{2}{|c|}{ just in time production } & 3.481 & .597 & medium & \\
\hline
\end{tabular}

The variable was treated through nine items which achieved an arithmetic mean of (3.481) and a standard deviation of (.597), and since the arithmetic mean is less than (3.68), we can say that the effect of (JIT) production system in taking investment decisions in the Jordanian industrial companies is medium. We notice that the item which states "(JIT) makes the delivery of stock depend on a limited number of suppliers" took the first rank with an arithmetic mean of (3.689) and a standard deviation of (.645) with high level of effect, while the item that states "The use of production control cards contributes in controlling production and the required specifications" was the least among the means of responses with an arithmetic mean of (3.373) and a standard deviation of (.678) with medium effect.

The researcher believes that the (JIT) system reduces the stock through adjusting production with sales orders and production requirements; and since the aim of (JIT) is to reduce the stock, lessen the loss and improve performance, this goal must be accompanied by taking sound investment decisions and requires concentrating the efforts of developing and improving the performance of the operations which are considered as constraints to the production line.

10.1.4 Fourth

Results of the descriptive statistics of the data related to the dependent variable (taking investment decisions)

Table4. The arithmetic means and standard deviations (taking investment decisions)

\begin{tabular}{|c|c|c|c|c|c|}
\hline serial & items & $\begin{array}{l}\text { arithmetic } \\
\text { means }\end{array}$ & $\begin{array}{l}\text { standard } \\
\text { deviation }\end{array}$ & $\begin{array}{l}\text { level of } \\
\text { importance }\end{array}$ & sequence \\
\hline \multicolumn{6}{|c|}{ Management accounting techniques contribute in : } \\
\hline 29 & $\begin{array}{l}\text { achieving the process of taking investment decisions } \\
\text { with high efficiency. }\end{array}$ & 3.651 & .716 & high & 5 \\
\hline 30 & facilitating the process of taking investment decisions. & 3.631 & .751 & high & 6 \\
\hline 31 & accelerating the process of taking investment decisions. & 3.851 & .655 & high & 1 \\
\hline 32 & $\begin{array}{l}\text { providing qualified competencies to deal with the } \\
\text { management accounting methods in taking investment } \\
\text { decisions. }\end{array}$ & 3.831 & .681 & high & 2 \\
\hline 33 & $\begin{array}{l}\text { choosing the best solution and analyzing the aspects of } \\
\text { the investment decision subject. }\end{array}$ & 3.617 & .741 & high & 7 \\
\hline 34 & $\begin{array}{l}\text { taking the investment decisions related to solving a } \\
\text { certain problem. }\end{array}$ & 3.747 & .729 & high & 4 \\
\hline 35 & $\begin{array}{l}\text { sharing the workers of the management accounting with } \\
\text { specialists to reach a sound investment decision. }\end{array}$ & 3.779 & .767 & high & 3 \\
\hline taking & Ivestment decisions & 3.729 & .710 & high & \\
\hline
\end{tabular}

This variable was treated seven items with an arithmetic mean of (3.729) and a standard deviation of (0.710), and 
since the arithmetic mean is higher than (3.68), we can say that the effect of management accounting techniques in taking investment decisions in the Jordanian industrial companies is high. We notice that the items which states that "The management accounting methods contribute in accelerating the process of making investment decisions took the first rank with an arithmetic mean of (3.851) and a standard de viation of (.665) with high le vel of effect, while the item which states that "The management accounting methods contribute in choosing the best solutions and analyzing the aspects of the investment decision subject" wasthe least among the mean of responses with an arithmetic mean of (3.617) and a standard deviation (.741) with high level of effect.

The researcher believes that management accounting is the corner stone in any company whether industrial, commercial or service and that it is the foundation of taking investment decisions as the need of the management to management accounting is determined by the sum of the financial and non-financial information and data, and in order for those companies to perform their different tasks related to planning, control, performance assessment and helping to prepare the comprehensive operational budget.

\subsection{Results of the Research Hypotheses Test}

\subsubsection{First}

Testing the first main hypothesis:

This hypothesis states "Thereis no statistically significant effect of the strategic management accounting techniques with its variables (target costing, balanced scorecard, just in time production system) in taking investment decisions in the Jordanian industrial companies".

Table 5. Results of the multiple linear regression test to the effect of management accounting techniques in taking investment decisions in the Jordanian industrial companies

\begin{tabular}{lccccccc}
\hline \multicolumn{1}{c}{ independent variable } & Sig. & $\mathrm{R}$ & $\mathrm{R}^{2}$ & & \multicolumn{2}{c}{$\begin{array}{c}\text { Calculated } \\
\text { T-value }\end{array}$} & \multicolumn{2}{c}{ Statisticaldecision } \\
\hline $\begin{array}{l}\text { management } \\
\text { techniques }\end{array}$ & accounting & 0.000 & .241 & .491 & .643 & 7.597 & $\begin{array}{l}\text { rejection of the null } \\
\text { hypothesis }\end{array}$ \\
\hline
\end{tabular}

Significant level $(\mathrm{a}=0.05)$ table value $\mathrm{T}=2.29$

It is clear the calculated T value is (7.597) while its table value is (2.29). Comparing the values, we find that the calculated value is higher than the table value, so the null hypothesis is rejected while the alternative hypothesis is accepted which states "There is a statistically significant effect of the strategic management accounting technics with its variables (target costing, balanced scorecard, just in time production system) in taking investment decisions in the Jordanian industrial companies". This is confirmed by the value of (Sig) which points to zero which is less than $5 \%$. it is also indicates that the variance in the independent variables $\left(\mathrm{R}^{2}\right)$ interprets the rate of (.491) of the changes in the dependent variable where the rest is attributed to other factors. The degree of influence B reached at (.643) which indicates the presence of a positive effect of the strategic management accounting techniques in taking investment decisions. As for testing the sub-hypotheses that stem from this hypothesis, the following tables show the results:

\subsubsection{First}

\section{Testing the first sub-hypothesis:}

This hypothesis states "There is no statistically significant effect for using target costing in taking investment decisions in the Jordanian industrial companies.

Table 6. Results of the simple linear regression test of the first sub-hypotheses

\begin{tabular}{lccccc}
\hline \multicolumn{1}{c}{ statement } & $\begin{array}{c}\text { correlation } \\
\mathrm{R}\end{array}$ & $\mathrm{R}^{2}$ & $\mathrm{~T}$ & $\mathrm{~B}$ & $\mathrm{Sig}$ \\
\hline $\begin{array}{l}\text { the effect of the target costing in taking investment } \\
\text { decisions }\end{array}$ & .357 & .125 & 5.546 & .347 & 0.000 \\
\hline
\end{tabular}

* The correlation is statistically significant at $(\mathrm{a} \geq 0.05)$ and $\mathrm{T}$ table value 1.671 .

The statistical analysis showed that (Sig) reached at (0.000) which means the presence of an effect of the target costing in taking investment decisions in the Jordanian industrial companies. The variance in the independent variable (R) explains the rate of (.357) of the variance in the dependent variable. This means that other factors affect taking investment decisions. $\mathrm{R}^{2}$ reached at (.125) which shows that the effect in decision making is resulted from target costing. The degree of influence B was (.347) which indicates the presence of positive effect of target costing in taking investment decisions. 


\subsubsection{Second}

\section{Testing the second sub-hypothesis:}

This hypothesis states "There is no statistically significant effect of using the balanced scorecard in taking investment decisions in the Jordanian industrial companies.

Table 7. Results of the simple linear regression test of the second sub-hypothesis

\begin{tabular}{lllcllll}
\hline \multicolumn{2}{c}{ statement } & & $\begin{array}{c}\text { correlation } \\
\mathbf{R}\end{array}$ & $\mathbf{R}^{2}$ & $\mathbf{T}$ & $\mathbf{B}$ & Sig \\
\hline $\begin{array}{l}\text { theeffectof the balanced } \\
\text { investment decisions }\end{array}$ & scorecard & in taking & .299 & .188 & 6.009 & 0.275 & .002 \\
\hline
\end{tabular}

* The correlation is statistically significant at $(\mathrm{a} \geq 0.05)$ and $\mathrm{T}$ table value of 1.671 .

The statistical analysis showed that (Sig) reached at (0.002) which means the presence of effect of using the balanced scorecard in taking investment decisions in the Jordanian industrial companies. The variance in the independent variable (R) explains the rate of (.299) of the variance in the dependent variable. This means that other factors affect taking investment decisions. As for $\mathrm{R}^{2}$, it reached at (.188) which indicates that the effect in taking investment decisions is resulted from the balanced scorecard. The degree of influence B reached at (.275) which means the presence of positive effect of the balanced scorecard in taking investment decisions.

10.2.1.3 Third

Testing the third sub-hypothesis

This hypothesis states "There is no effect of using (JIT) production system in taking investment decisions in the Jordanian industrial companies.

Table 8.Results of the simple linear regression test of the third sub-hypothesis

\begin{tabular}{lccccc}
\hline \multicolumn{1}{c}{ statement } & $\begin{array}{c}\text { correlation } \\
\mathrm{R}\end{array}$ & $\mathrm{R}^{2}$ & $\mathrm{~T}$ & $\mathrm{~B}$ & $\mathrm{Sig}$ \\
\hline $\begin{array}{l}\text { the effect of the } \\
\text { (JIT) in taking investment decisions }\end{array}$ & .340 & .213 & 4.981 & 0.330 & .000 \\
\hline
\end{tabular}

* The correlation is statistically significant at $(\mathrm{a} \geq 0.05)$ and $\mathrm{T}$ table value of 1.671 .

The results of the statistical analysis showed that (Sig) reached at $(0.000)$ which means the presence of effect of the (JIT) production system in taking investment decisions in the Jordanian industrial companies. The variance in the independent variable $(\mathrm{R})$ explains the rate of (.340) of the variance in the dependent variable which means that other factors affect taking investment decisions. As for $\mathrm{R}^{2}$, it reached at (.213) indicating that the effect in decision making is resulted from the just in time production system. The degree of influence B was (.330) which means the presence of a positive effect of the (JIT) production system in taking investment decisions.

\section{Results}

The results of the research revealed that there is an effect of the management accounting techniques with its variables (target costing, balanced scorecard, JIT production system) in taking investment decisions in the Jordanian industrial companies. As for testing the sub-hypotheses, it was as follows:

1- Theresults revealed an effect of target costing in taking investment decisions in the Jordanian industrial companies. The results of the descriptive and analytical statistics of this variable showed that the responses to the items of this variable were at medium level. It was clear that the costs of products are affected by the costs of sharing raw materials and the requirements and process of the production process. The operational engineering can be designed in a manner that reduces the production costs and suits the provision of new future models.

2- The results showed the presence of an effect of the balanced scorecard in taking investment decisions in the Jordanian industrial companies. The results also showed that the responses to the items of this variable were at medium level and it was clear that the company tries to harmonize the individual goals and the division's goals with the strategy of the company and provides a strategic communication plan which connects the top management with individuals. It was also clear that the company seeks to coordinate between the individual and organizational performance to reach at the objectives.

3- The results showed the presence of an effect of the (JIT) production system in taking investment decisions in the Jordanian industrial companies and also showed that the responses to the items of this variable were at medium level. It was clear that this system helps to make the process of stock delivery 
dependent on a limited number of suppliers. It was also clear that the (JIT) production system makes it possible to depend on a low level of stock to reduce the loss and size of defective products.

\section{Recommendations}

1- The Jordanian industrial companies are to use modern management accounting methods and to take care of their different fields to be able to interact and respond to the environmental, social and economic changes.

2- Developing the management accounting departments and caring for continuous training and teaching to raise the efficiency of the management accountants in the Jordanian industrial companies and holding training courses to acquaint them the management accounting systems and uses and the continuous development in their methods.

3- Increasing the awareness of people in charge in the Jordanian industrial companies to the important role played by the management accounting methods in providing the information that helps the investors to take investment decisions in those companies.

4- Assuring the Jordanian industrial companies to accept and adopt the balanced scorecard technique to be properly applied depending on workers who enjoy sufficient awareness to apply this technique to enable the company to assess its performance in harmony with its surrounding environment.

5- The top managements of the Jordanian industrial companies are to create the appropriate grounds to transform from the applied traditional systems to the (JIT) production system and to view all the as pects and constituents of this system together with its benefits for the company.

\section{References}

Abu Khashabah, A. A. (2011). Concepts and Characteristics of Investment Decisions and the Effecting Factors in It, and the Different Configurations for It, Public ations of Al-Sharq Academy of Applied Sciences, Cairo.

Abu Zayd, F. R. B. (2010). Usage of Target Cost Method for the Purpose of Cost Reduction in the Oil and Gas Companies in the Libyan Arab Jamahiriya in Light of Environment Development and Quality Requirements, a Master Thesis, Arab Academy for Financial and Banking Sciences, Amman, Jordan.

Abu, J., Mohammad, M., \& Aql, I. (2016). the Economical Feasible Study. Amman: Dar Ghaida' for Publication and Distribution.

Adeyemi, S. L. (2010). Just-in-Time Production Systems (JITPS) in Developing Countries -The Nigerian Experience.J SocSci, 22(2), 145-152.https://doi.org/10.1080/09718923.2010.11892795

Adler, R., Everett, A., \& Waldron, M. (2012). Advanced Management Techniques in ManafacturingUtiliztion, Benefits and Barriers to Implementation, Accounting Forum, 1, 131-150.

Ali, H. (2016). Advance Administrative Accounting, Al-Dar Al-Jami'iyyah, Alexandria, Egypt.

Al-Matarneh, G., Al-Beshtawi, \& Sulayman. (2007). The effect of Applying the Production Cost System in the Specified Time (JIT) on the Operational Performance in the Jordanian Industrial Companies. (Administrative Sciences) Studies Journal, the University of Jordan- Jordan, 34(2), 299-317.

Al-Nashar, T. (2014). The Relationship between the Added Costs Frame and the Indicators of non-Suitability Cost System, a Proposed Frame, an Applied Study. the Journal of Commerce Faculty of Scientific Researches, Cairo, 41(1), 283-335.

Al-Nsour, S., \&Ali, A. K. (2016). The Impact of Using Modern and Traditional Administrative Accounting Methods on Profitability in the Public Industrial Companies Ltd enrolled in Amman Fund Market- an Analytical Study. a PHD Thesis, the Islamic Sciences University, Jordan.

Al-Tarawneh, B. M. (2015). The Strategic Role for Applying the Costs' System Based on the Activities Basis $(\mathrm{ABC})$ : a Field Study in the Medicine Industrial Companies working in Jordan. a PHD Thesis, Al-Jinan University, Tripoli, Lebanon.

Dhaher, A. H. (2016). Administrative Accounting, Dar Wael for Publication, Amman, Jordan.

Fakhr, N., \& Al-Dulaimi, K. (2012). Industrial Cost Accounting, International Scientific House for Publication and Distribution, and Dar Al-Thaqafa for Publication and Distribution, Amman, Jordan.

Ghunaimi, S. M. A. (2014). The Effeciency Extent of Target Cost Role in the Increase of Competitive Ability of Commercial Bank Services- an Analytical Study. Commercial Research Journal, 3(1), 34-51. 
Horngren, C. T., Sundem, G. L., \& Stratton. W. O. (2005). Introduction to Management Accounting. Upper Saddle River: New Jersey, Prentice Hall.

Jaradat, Z. A. K., \& Al-Shubayl, S. O. (2014). The Limit of Administrative Accounting Contribution in the Emergence of Commercial Banks. Al-Manarah Journal, 19(4), 257-296.

Jawad, S. M., \& Al-Rifaie, H. O. (2010), the Role of Appropriate Costs in Rationalizing the Operational Decisions, an Applied Study in Al-Furat Public Corporation for Chemical Industries. Babil University Journal, Humanitarian Sciences, 18(1), 1-13.

Judah, A. H. M., Khalil, M. N., \&Khreisat, U. M. (2011). The Extent of Using Administrative Accounting Methods in the Jordanian Industrial Public Company Ltd.: (A Field Study). Management and Economics Journal, 87, 13-37.

Kaplan, R., \& Norton, D. (2005). Measuring the Strategic Readiness of Intangible Assts. Harvard Business Review.

Kato, Y. (2003). Target Costing Support System: Lesson from Leading Japanese Companies. Management Accounting Research, Japan, 4(1), 33-46. https://doi.org/10.1006/mare.1993.1002

Kee, R. (2010). The Sufficiency of Target Costing for Evaluating Production- Related Decision. International Journal of Production Economic, 126(2), Augest, 204-211.https://doi.org/10.1016/j.ijpe.2010.03.008

Qwaider, F. (2012). Finance as an Instrument for Continuity of Investment Projects: Study on the Case of Cap-Ti Company for Investment Services during the period 2009-2012. A Master Thesis, Qasedi Mirbah University, Warqalah, Algeria.

Sakurai, M. (2008). Target Costing and How to Use It. Journal of Cost Management, 3(2), 39-51.

Salem, I. A. (2015). Studies in Economics, Dar Beit-al-Hikmah for Publication and Distribution, Baghda.

Schroeder, R. G.(2016). Operation Management, McGraw-Hill Book Company, New York. The Annual Statement of Amman Financial Market, for the year 2016.

Theresa Libby, Steven E Salterio, and Alan Webb. (2004). The Balanced Scorecard: The Effects of Assurance and Process Accountability on Managerial Judgment. The Accounting Review.Sarasota, 79(4), 20-41.

Wegmann, G. (2013). Compared Activity - Based Costing Case Studies in the Information System Departments of Tow Groups In France; A Strategic Management Accounting Approach. International Conference on Business and Information, 7(1), 72-93.

Yoshikawa, T., Innes, J., Mitchell, F., \& Masayasu, T. (2013).Target Cost, Chapter Four, Contemporary Cost Management, Chapman and Hall.

Zirar, H. (2013). The Role of Financial Feasibility Study in making the Investment Decision: A Study of Investment Loan case at the Algerian National Bank for the period 2010-2013, Qasedi Mirbah University, Waraqlah, Algeria.

\section{Copyrights}

Copyright for this article is retained by the author(s), with first publication rights granted to the journal.

This is an open-access article distributed under the terms and conditions of the Creative Commons Attribution license (http://creativecommons.org/licenses/by/4.0/). 